\title{
Antecedents of panic buying behavior during the COVID-19 pandemic
}

\author{
Annastasia Melisse Putri ${ }^{a^{*}}$, Avior Retsan ${ }^{a}$, Huimanto Andika ${ }^{a}$ and Evelyn Hendriana ${ }^{a}$
}

${ }^{a}$ Business Management, Management Department, Binus Business School Master Program, Bina Nusantara University, Jakarta, Indonesia

\section{H R O N I C L E}

Article history:

Received: November 20, 2020

Received in revised format:

December 282020

Accepted: January 28, 2021

Available online:

January 28, 2021

Keywords:

Consumer anxiety

COVID-19

Media credibility

Panic buying

Social contagion

\section{A B S T R A C T}

The new Coronavirus disease (COVID-19) pandemic triggers panic buying behavior among consumers in several countries. Previous research on panic buying behavior is less likely to look at the phenomenon from the perspective of consumers (demand-side). Therefore, this study aims to examine the influence of media credibility and social contagion on panic buying behavior and the mediating effect of consumer anxiety in the relationship between media credibility, social contagion and panic buying behavior. Data was collected from young and adult consumers in Greater Jakarta, Indonesia using convenience sampling techniques. Three hundred and fifty responses were collected through an online survey. The hypotheses were tested using structural equation models that could simultaneously analyze the effects of variables in the complex model. The results indicate that media credibility does not have a significant effect on consumer anxiety and panic buying. On the other hand, social contagion has a direct and indirect influence on consumer anxiety. Likewise, consumer anxiety mediates the relationship between social contagion and panic buying behavior. The findings from this research can be used by manufacturers and retailers to maintain goods availability during the pandemic, and the government as a basis for economic decision making. This research also contributes to development of the academic literature related to consumer behavior during a pandemic.

\section{Introduction}

Nowadays, the world is frightened by the outbreaks of COVID-19 (coronavirus disease -19). The virus, which was first identified in Wuhan, China, has spread very quickly throughout the world. COVID-19 has been categorized as a pandemic by the WHO due to the uncontrollable spread of the virus worldwide. As of June 8, 2020, the number of reported cases has reached more than 6,931,000 cases (Infectionemerging, 2020). For Southeast Asia, Indonesia is one of the countries with the highest number of cases and above the global average (worldometers, 2020). The number of infected patients has reached more than 32,033 people as of June 8, 2020, where the highest number of cases is concentrated in three provinces, namely Jakarta with 8,121 cases, West Java with 2,424 cases, and East Java with 6,313 cases (Infectionemerging, 2020). Pandemics trigger fear and worry in the communities due to high uncertainties. These feelings are centered on the individual's mind which stimulates panic buying behavior. In the COVID-19 pandemic, it is evident from the behavior of the public who uncontrollably buy products that are able to prevent the transmission of viruses such as masks and hand sanitizers. The response was a reaction to the COVID-19 outbreak (van Bavel et al., 2020). Therefore, a pandemic that is not controlled properly will have a negative impact on the economy. An issue that originates from rumors can trigger a social panic, which leads to panic buying (Qiu et al., 2018). Panic buying occurs because of the information that is shared and delivered by individuals, governments, and community leaders (The Bronfenbrenner Center for Translational Research, 2020). As a social creature, an individual will seek interactions with others, thus enabling a social contagion. Burgess et al. (2018) stated that a social contagion can be

* Corresponding author.

E-mail address: huimantoandika02@gmail.com (A. M. Putri) 
caused by interactions between individuals (homophily interactions) and interactions that are caused by influence. For example, in the United States, the individuals' anxiety related to their personal economic condition increased from $47 \%$ to $74 \%$ within just 11 days because they believed that the virus transmission and the mortality rate caused by COVID-19 was much higher than the official statements from experts (Fetzer et al., 2020). The government's actions to prevent the virus outbreak will be more effective if individuals can oppress their anxieties and negative opinions toward the pandemic. In contrast, when many individuals are anxious and hold negative opinions about the pandemic, it may result in an economic downturn that triggers panic buying behavior (Fetzer et al., 2020). This happened during World War II, when heavy media coverage encouraged individuals to do panic buying (Merrefield, 2020).

Yap and Chen (2020) revealed that one's opinions in social media might trigger stress, fear, and uncertainty in the public, thereby encouraging panic buying behavior. Panic buying behavior is inseparable from media credibility, in both offline media and online media, in conveying information to the public. Viviani and Pasi (2017) stated that individuals are often faced with the problem of information accuracy caused by the lack of professional supervisors to oversee the news content circulating in the public. As a result, the recipients of the information do not know whether the information comes from a reliable source or not (Li \& Suh, 2015). Therefore, credible media sources should not withhold information to the public and must convey accurate information to reduce panic (Yu et al., 2016). If an individual considers information about the effects of the COVID19 pandemic to be reliable, the person will worry or feel anxious to take appropriate steps to anticipate the outbreaks. This might trigger panic buying behavior during a pandemic. It can be concluded that panic buying behavior may be influenced by psychological and social factors such as media coverage, social interactions, and the anxieties as experienced by individuals. However, to the best of our knowledge, a limited amount of research has studied this phenomenon from the consumers' perspective (demand-side), in which previous studies are mostly focused on the perspective of retailers or the supply-side (e.g., Shou et al., 2011; Tsao et al., 2018; Zheng et al., 2020). In addition, empirical studies that look at a social contagion as a factor that can influence a person's buying behavior are still limited. Based on this review, this study aims to examine the effects of media credibility, a social contagion, and consumer anxiety towards panic buying behavior.

\section{Literature review}

\subsection{Panic buying}

Panic buying is a situation where many people impulsively buy food, fuel, etc., as much as possible because they are worried about the possibility of something bad happening in the near future (Utami, 2020). Panic buying is a form of consumer behavior that is defined as the actions of consumers to obtain, consume, and spend products and services, including processes that precede and follow these actions (Sunarto, 2018). The behavior is influenced by cultural, social, personality, and psychological factors (Bahari \& Ashoer, 2018). Buying decisions are also influenced by other people's attitudes toward one's buying behavior, the motivation to follow others' desires, and unexpected situations (Sunarto, 2018). Panic buying behavior is more likely to be influenced by uncertainties or risky conditions that affect the psychological conditions of consumers. Panic behavior occurs when the following factors happen. First, people sense an immediate dangerous circumstance. Second, there are only a few solutions available to avoid the situation. Third, individuals feel that the available solutions are completely obstructed so that an escape plan is needed in this situation. Fourth, there is a lack of communication about the situation that causes panic (Kulemeka, 2010). Helsloot and Ruitenberg (2004) found that in a dangerous situation, fear arises first because of uncertainty. Then it will quickly diminish, and people will begin to look for ways to save themselves and others. Instead of panicking, some people choose to help others. In this context, the COVID-19 pandemic causes people to swarm and buy supplies in large quantities. This is the result of social influence in the form of copying the behaviors of others who do panic buying. The media also plays a role, where credible media may influence people not to do panic buying behavior. Furthermore, panic buying behavior is also caused by the psychological traits of the individual, where the perception of COVID-19 may create fear and anxiety which leads one to look for products that are considered important to deal with a COVID-19 pandemic situation without much consideration, thus encouraging the individual to do panic buying. These three factors are the focus of this study and are discussed in the following subsections.

\subsection{Media credibility}

Credibility is a situation or condition that can be trusted and accounted for (Abidin et al., 2017). For the media context, a credible media conveys information that can be trusted by the audience. In addition, the media credibility can be seen from the information source, whether the source can be legally accounted for (Abidin et al., 2017). Based on this explanation, media credibility is measured from two aspects, namely the credibility of the information content and the credibility of the source. The first aspect is the credibility of information content that is related to the theory of objectivity. Referring to McQuail (2010, cited from Handiyani \& Hermawan, 2017, p. 55), objectivity is a condition where the news presented in the media is in accordance with the facts or reality. Objectivity is important as it enables the society to assess whether the news presented by the media can be trusted or credible. News credibility presents the reliability of the news that may foster trust in the public. The public will be more confident in the news presented in accordance with the facts, disclosure of full information, and origin from credible sources (Handiyani \& Hermawan, 2017). The next aspect is the source credibility which is defined as the 
audience's perception of the source credibility in delivering the information (Soenarno et al., 2015). The information technology advancement that enables the fast delivery of information via the Internet has its own challenges. The Internet enables individuals to exchange information easily, which makes the tracing of an information source become harder (Soenarno et al., 2015). Source credibility can be seen from two dimensions, namely expertise and trust (Soenarno et al., 2015). Expertise is the impression formed by the communicant about the communicator's ability in relation to the topic being discussed. An intelligent, capable, expert, knowledgeable, experienced, and trained communicator will be considered as a valued expert. While trust is the audience's impression of the communicator relating to his personal characteristics including being honest, sincere, moral, fair, polite, and ethical (Kosasih et al., 2017).

Highly credible sources have a large impact on audiences' opinions, as they are able to produce more attitude changes compared to sources that have low credibility. When one's arguments are properly supported, the expertise and reliability of the communicator can determine the trust given to him/her. In other words, the audience will trust and be more likely to accept messages conveyed by individuals who have expertise and credibility in their fields (Jurnaiti et al., 2017). Kawengian et al. (2017) illustrated the role of credibility in the communication process by arguing that experts will be more persuasive than non-experts. A message will be more effective if the message is delivered by a credible and expert source since the individual can enhance trust for the audience. When the audience trusts the information sources, they will consider the message delivered by the source as being true and close to the reality. The source's confidence in the information is determined by one's expertise in carrying out one's work and the ability to be trusted (Jurnaiti et al., 2017). Negative news can modify the audience's perceptions on a phenomenon that ultimately changes their mindsets. A research by Szabo and Hopkinson (2007) showed that broadcast news can trigger negative emotions in the form of high anxiety. Negative news, especially that which is widely spread on the Internet, is generally provocative, frightening, and unclear. Those factors can stimulate an individual's anxiety that is associated with uncertain, insecure, and unpleasant feelings. Anxiety is defined as an uncertain feeling, panic, fear without knowing what is feared, and an inability to eliminate the feeling of being worried and fidgety (Herwanto \& Febyani, 2015). In this study context, if consumers get information about the COVID-19 pandemic from a trusted media source, they will feel calmer because they will know the real conditions that occur in society. That is because the content of the news and sources of information are valid to overcome the doubts of consumers in dealing with an uncertain situation caused by the COVID-19 pandemic. This argument indicates that the credibility of the media can influence the perceptions and actions of the audience, where a non-credible media source can create anxieties, fears, and worries. Based on this argument, the following hypothesis is proposed:

\section{$\mathbf{H}_{\mathbf{1}}$ : Media credibility has a negative effect on the consumers' anxiety.}

The media, including social media, also plays a role in buying decisions. According to Pamungkas and Zuhroh (2016), social media has several advantages in terms of accessibility, speed, longevity/volatility, interactivity, and reach that make its effects stronger than the traditional media. Compared to the traditional media, social media is easy to access because it requires little or no cost. Content on social media is available to everyone who is in a network, forum, or community as soon as it is published and it can be accessed for a long time, or even forever. In addition, social media can accommodate two or more channels of communication and unlimited access to all available content. Research from Suciningtyas (2012) revealed that communication through the media has a positive effect on consumer buying decisions. Other research also concluded that social media has a significant direct effect on consumer buying interest (Putri, 2016). In this study context, however, the credibility of the media used by consumers to obtain information about the COVID-19 pandemic is predicted to reduce the potential for panic buying. The more credible the source and content of the news is, the more consumers will not be lured into panic buying behavior because they will feel the situation is under control. Therefore, this study proposes the following hypothesis:

\section{$\mathbf{H}_{2}$ : Media credibility has a negative effect on panic buying.}

\subsection{Social contagion}

Social contagion is a general phenomenon that can be observed in various social contexts such as in the workplace (Burgess et al., 2018) and at schools (Burgess et al., 2018; Lestari et al., 2013). The occurrence of social contagion can also be found in social media (Burgess et al., 2018). Social contagion occurs intentionally or unintentionally either on the parties who give an influence or who are influenced. The influencing parties can prompt and transmit their behaviors to others whether intentionally or not; while the affected individuals may adopt these behaviors consciously or unconsciously (Angst et al., 2010; Huang, 2010). A social contagion refers to the fact that an individual's psychological condition can spread like a virus within a social group (Wijayanti \& Sulistiobudi, 2018). Christakis and Fowler (2011) argued that the spread of cohesive behavior is vulnerable in a peer group network, so that there are many possibilities for some behaviors to spread in a peer group, such as smoking, consuming alcohol, and overeating causing obesity. Behavior contagion research can be broken down into six broad areas, based on the nature of behaviors that are scattered among others: hysterical contagions, deliberate self-harm contagions, contagions of aggression, rule violation contagions, consumer behavior contagions, and financial contagions (Marsden, 1998). In scattered collectivistic, where the contagion of aggression is physical aggression or verbal aggression mediated by aggressive media that is seen by the respondents, an aggressive audience is more likely to prefer violent shows (Atkin et al., 1979). 
Individuals may also be influenced by others emotionally, which is known as an emotional contagion. The term 'emotional contagion' was originally defined by McDougall (1920, cited from Marsden, 1998, p. 2) as "the principle of direct emotional induction through primitive sympathetic responses", and then later redefined by Sullins (1991, cited from Marsden, 1998, p. 2) as a "process by which individuals seem to capture" the moods of those around them. This can be seen from the individuals' tendency to automatically harmonize their facial expressions, sounds, and postures with others in their immediate environment (Hatfield et al., 1993). These behavioral cues then trigger appropriate emotions in the feedback system. Doherty (1997) developed and validated the scale of emotional contagion in the form of mood (Hsee et al., 1992), anxiety (Behnke, Sawyer, \& King, 1994), fear (Gump \& Kulik, 1997), awards (Freedman \& Perlick, 1979), and enjoyment (Freedman et al., 1980). Based on this explanation, social contagion is considered to have a positive effect on consumer anxiety related to the current COVID19 pandemic. This is because social contagion can affect one's emotions, where the panic of others in dealing with the COVID19 pandemic can stimulate anxiety in other individuals. Therefore, we propose the following hypothesis:

\section{$\mathbf{H}_{3}$ : Social contagion has a positive effect on consumer anxiety.}

Social contagion may affect one's behavior as presented in the study in a financial market. Social contagion in the financial sector is manifested in the stock market behavior which is contagious from one country to another as the result of panic selling behavior that affects the whole world (Lux, 1998). In the context of the COVID-19 pandemic, social contagion is predicted to have a positive effect on panic buying activities. The panic buying behavior of some people during the COVID-19 pandemic is copied by other individuals, so that it becomes a spreading behavior. This is presented in the following hypothesis:

\section{$\mathbf{H}_{4}$ : Social contagion has a positive effect on panic buying.}

\subsection{Consumer anxiety}

Annisa and Ifdil (2016, p. 94) stated that "Anxiety is similar to fear but with a less specific focus, whereas fear is usually a response to some immediate threats, whereas anxiety is characterized by concerns about the unexpected danger that lies in the future". Anxiety comes from the Latin word "angustus" which means rigid, and "ango, anci" which means to suffocate. Anxiety is an unpleasant emotion, such as an uneasy, confused, and anxious feeling that is characterized by the extent of one's worry, concern, and fear that is sometimes experienced in different situations (Kumbara et al., 2018). Lestari et al. (2013) mentioned anxiety as being a state of feeling where individuals feel weak, scared, and unable to act and behave rationally to what they should. Anxiety arises as a response to stress or conflict. This is common when a person experiences a change in one's life and must adapt with it (Lestari et al., 2013). Nevid et al. (2005, cited from Annisa \& Ifdil, 2016, p. 94), defined anxiety as "an emotional state that has the characteristics of physiological arousal, an unpleasant feeling of tension, and a comprehensive feeling that something bad will happen". From the various notions of anxiety that have been described above, it can be concluded that anxiety is an emotional condition presented through the feelings of tension, fear, and discomfort due to something that is not clear, lies in the future, and does not necessarily occur. Ghufron and Risnawita (2014, cited from Annisa \& Ifdil, 2016, p. 96) said that anxiety was shaped by negative experiences in the past and irrational thoughts. Anxiety can arise when individuals face the same discomfort situation as in the past, such as the experience of failure in a test. In addition, anxiety can be stimulated by irrational thoughts which are divided into four forms, namely catastrophic failure, perfection, approval, and excessive generalization. Muchnisa and Sulaiman (2019) found that consumer anxiety had a significant positive effect on compulsive buying. A research by Lejoyeux (1997) reported that depression triggered compulsive buying because this phenomenon was repeatedly found in depressed patients. Consumer anxiety is at the core of compulsive buying and there may also be something else that occurs simultaneously as a cause and effect of such behavior (Muchnisa \& Sulaiman, 2019). Larasati and Budiani (2014) stated that compulsive behavior usually occurs in someone who has low selfconfidence, a high level of imagination, and a high level of depression, anxiety, and obsession. Similar to compulsive buying, panic buying is more driven by the individuals' psychological needs rather than utilitarian needs, and purchase decisions are made without thorough considerations. An individual's irrational thoughts that something bad will happen due to the COVID19 pandemic can cause one to be fearful about situations which are beyond the person's control. As a result of an individual's anxiety and fear, one is likely to panic by buying basic items and other goods to prevent the person from contracting the virus. Based on previous studies, it is expected that consumer anxiety has a positive effect on panic buying because the more anxious the consumer is during the COVID-19 pandemic, the more likely the individual will buy various products that are deemed necessary during the pandemic without much consideration. Therefore, we propose the following hypothesis:

\section{H5 : Consumer anxiety has a positive effect on panic buying.}

Based on an explanation of the interrelationships between the variables above, this study examines the five hypotheses shown in Fig. 1. 


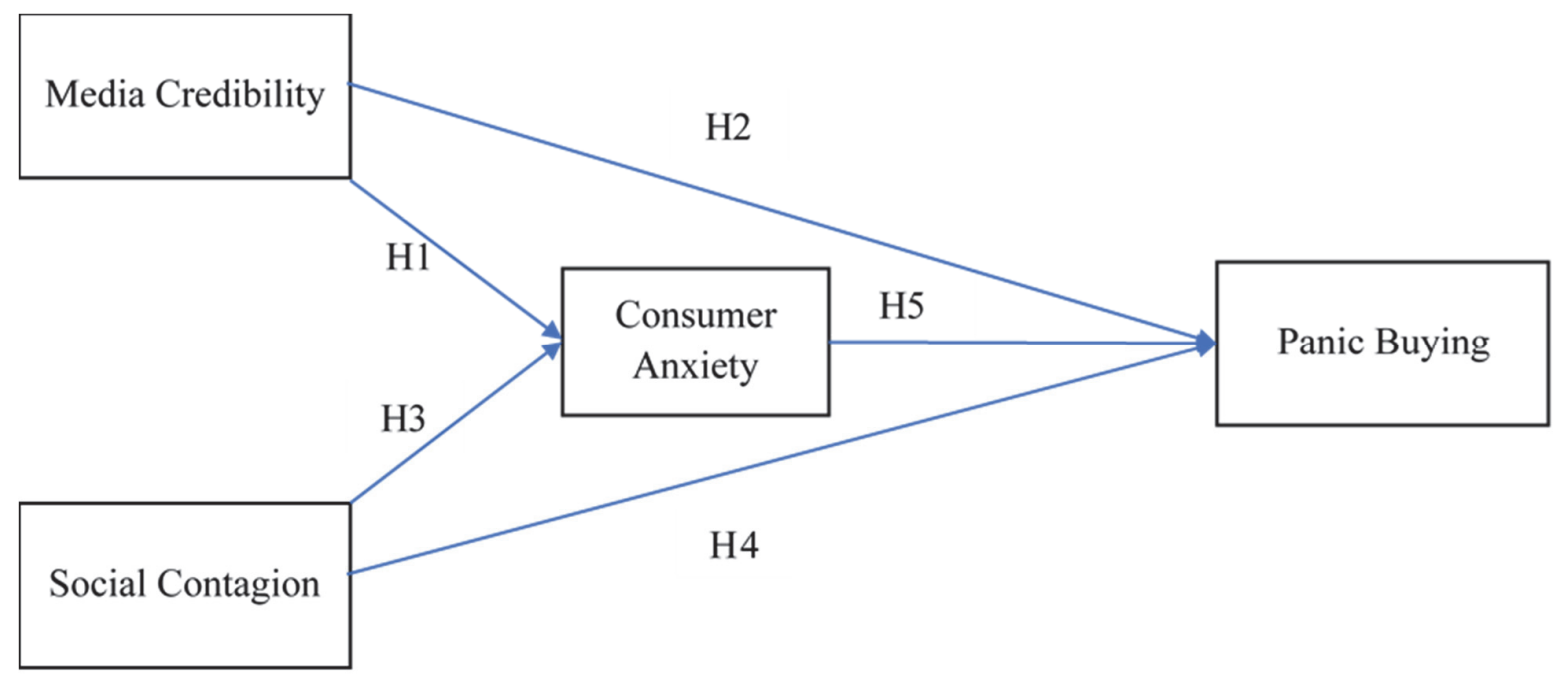

\section{Research methods}

Fig. 1. Theoretical Framework

\subsection{Data Collection and Measurement Techniques}

This study aims to examine the effects of media credibility, consumer anxiety, and social contagions on panic buying behavior by applying a quantitative research design. Data was collected from individuals who ever did panic buying during the early period of the COVID-19 pandemic in Indonesia. This study focused on individuals who live in Jakarta, Bogor, Depok, Tangerang, and Bekasi, as those cities had the highest number of COVID-19 cases in Indonesia. As of June 8, 2020, there were 32,033 cases in total, which consisted of 8,121 cases in Jakarta, 2,424 cases in West Java with most of the cases found in Depok, Bogor, and Bekasi, and 1,047 cases in Banten with the highest number of cases in Tangerang and Tangerang Selatan (Infectionergerging, 2020; Widigda \& Setyaningrum, 2018). Due to the number of cases and the incremental daily transmission rate, the Indonesian government forced these cities to implement large-scale social restrictions (PSBB). Samples were selected using convenience sampling techniques where the respondents were those who might be able to provide information about the factors that lead them to purchase a large quantity of staple goods and COVID-19 transmission prevention items such as masks and hand sanitizers. Data was collected by distributing online questionnaires to 408 target respondents, in which 350 samples could be used for hypothesis testing. This resulted in a usable response rate of $86 \%$. The questionnaire consisted of two parts, where the first part was about the demographics of the respondents and the second part was about the measurement of the variables being studied. The variable of media credibility was considered as a multidimensional variable. The dimension of medium credibility was measured by 5 items, while the dimension of message credibility was measured by 8 items adapted from Li and Suh (2015). Social contagion was measured by 7 items from Ple and Demangeot (2019). The mediating variable in this study, namely consumer anxiety, was measured by 8 items adapted from Darrat et al. (2016) and Hutjens (2014). Finally, panic buying behavior was measured by 15 items adapted from Darrat et al. (2016) and Guale and Beltrán (2017). The measurement items can be found in the Appendix. All measurement items were measured using a 5-point Likert scale where 1 is strongly disagree and 5 is strongly agree.

\subsection{Method for Data Analysis}

To test the hypotheses, the data was analyzed using structural equation modelling (SEM). This method can analyze the influence of variables in complex models simultaneously. This study was more predictive in nature since previous research on panic buying mostly focused on the perspective of the product provider (supply-side), and only a few discussed it from the perspective of the buyer (demand-side). Hence, we utilized PLS-SEM for data processing, as this method is more appropriate for this study purpose (Hair et al., 2016). The PLS-SEM model is a path model that shows the effects of several variables on other variables in the causal sequence that has been hypothesized previously (Garson, 2016). Based on previous studies that focused on the demand-side, as far as we know, no research has linked it to a social contagion. Therefore, we chose PLS-SEM to identify the main variables that influence panic buying behavior by maximizing the ability of independent variables and mediators in explaining the dependent variable. In addition, PLS-SEM is suitable to be used for testing models that have formative variables/constructs (Hair et al., 2016) such as the media credibility variables in this study. To predict the influence between the variables, this study used the SMART PLS Version 3.0 software.

\section{Result and Discussion}

\subsection{Respondent Profile}

Referring to the demographic profile of the respondents in Table 1, the gender distribution of the respondents was quite similar. Most of them are young and hold undergraduate degrees. As many as $50 \%$ of respondents live in Jakarta which is the epi-center of the spread of COVID-19 in Indonesia. The majority are middle-class who have expenditures below IDR 5 million 
(equivalent to USD 352.83). In line with their age distribution in which most of the respondents are millennials, they often access social media for information about COVID-19.

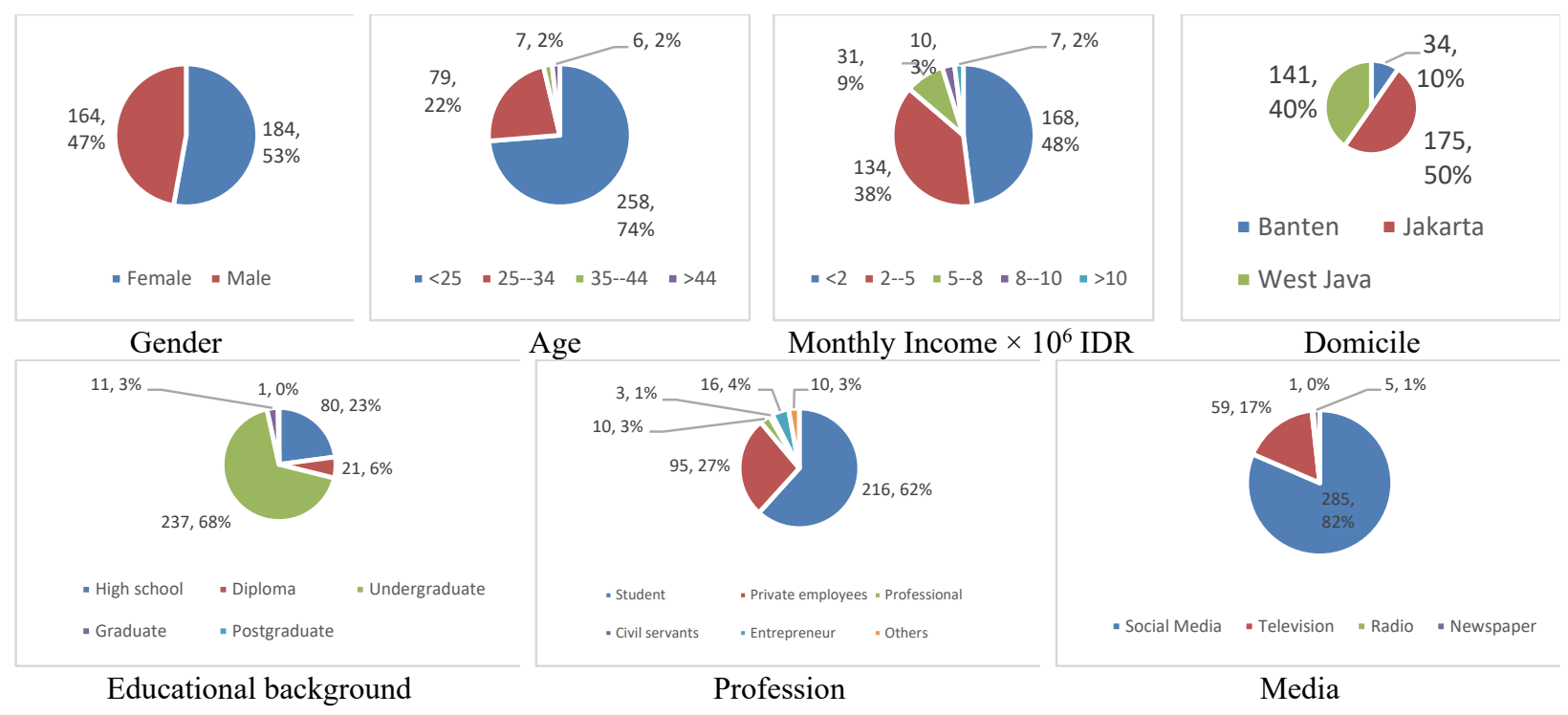

Table 1

Fig. 1. Profile of Respondents Descriptive Statistics

Results of Descriptive Statistics, Validity, and Reliability

\begin{tabular}{|c|c|c|c|c|c|c|}
\hline \multirow[t]{2}{*}{ Variables \& items } & \multicolumn{2}{|c|}{ Descriptive Statistics } & \multicolumn{2}{|c|}{ Construct validity } & \multicolumn{2}{|c|}{ Reliability } \\
\hline & Average & S.D. & $\begin{array}{l}\text { Factor load- } \\
\text { ing }\end{array}$ & AVE & Cronbach's alpha & $\begin{array}{l}\text { Composite reli- } \\
\text { ability }\end{array}$ \\
\hline Panic Buying: & & & & 0.5180 & 0.8655 & 0.8951 \\
\hline PB8 & 2.620 & 1.119 & 0.6349 & & & \\
\hline PB9 & 2.717 & 1.192 & 0.6546 & & & \\
\hline PB 10 & 2.674 & 1.222 & 0.7563 & & & \\
\hline PB11 & 2.574 & 1.138 & 0.8154 & & & \\
\hline PB12 & 3.474 & 1.033 & 0.7141 & & & \\
\hline PB13 & 3.577 & 0.985 & 0.6518 & & & \\
\hline PB14 & 2.794 & 1.140 & 0.7451 & & & \\
\hline PB15 & 2.877 & 1.166 & 0.7651 & & & \\
\hline \multicolumn{7}{|l|}{ Media Credibility: } \\
\hline Medium Credibility: & & & & 0.5874 & 0.8228 & 0.8762 \\
\hline MEDC1 & 4.300 & 0.724 & 0.8313 & & & \\
\hline MEDC2 & 4.343 & 0.703 & 0.8272 & & & \\
\hline MEDC3 & 3.983 & 0.868 & 0.7257 & & & \\
\hline MEDC4 & 3.571 & 0.959 & 0.6961 & & & \\
\hline MEDC5 & 3.860 & 0.835 & 0.7417 & & & \\
\hline Message Credibility: & & & & 0.6496 & 0.9219 & 0.9365 \\
\hline MESC1 & 3.903 & 0.840 & 0.8211 & & & \\
\hline MESC2 & 3.671 & 0.820 & 0.6782 & & & \\
\hline MESC3 & 3.780 & 0.869 & 0.8102 & & & \\
\hline MESC4 & 3.886 & 0.788 & 0.8714 & & & \\
\hline MESC5 & 3.726 & 0.900 & 0.8559 & & & \\
\hline MESC6 & 3.780 & 0.825 & 0.8299 & & & \\
\hline MESC7 & 4.017 & 0.744 & 0.7986 & & & \\
\hline MESC8 & 4.089 & 0.804 & 0.7665 & & & \\
\hline Consumer Anxiety: & & & & 0.5616 & 0.8886 & 0.9109 \\
\hline CA1 & 2.734 & 1.229 & 0.7425 & & & \\
\hline $\mathrm{CA} 2$ & 2.789 & 1.205 & 0.7043 & & & \\
\hline CA3 & 2.751 & 1.248 & 0.8340 & & & \\
\hline CA4 & 2.214 & 1.239 & 0.7401 & & & \\
\hline CA5 & 3.366 & 1.175 & 0.7875 & & & \\
\hline CA6 & 3.749 & 1.087 & 0.7324 & & & \\
\hline $\mathrm{CA} 7$ & 3.829 & 1.011 & 0.6997 & & & \\
\hline CA8 & 3.726 & 1.036 & 0.7458 & & & \\
\hline Social Contagion: & & & & 0.5274 & 0.7826 & 0.8470 \\
\hline $\mathrm{SC} 1$ & 3.649 & 0.881 & 0.6324 & & & \\
\hline $\mathrm{SC} 2$ & 3.529 & 0.925 & 0.7306 & & & \\
\hline $\mathrm{SC} 3$ & 3.597 & 0.956 & 0.6729 & & & \\
\hline $\mathrm{SC} 4$ & 2.671 & 1.227 & 0.8101 & & & \\
\hline $\mathrm{SC} 7$ & 2.497 & 1.244 & 0.7707 & & & \\
\hline
\end{tabular}


Table 1 shows the descriptive statistics, validity, and reliability of the items. Based on the descriptive statistics, on average, the respondents perceived both the medium (means between 3.571 and 4.343) and the message (means between 3,671 and $4,089)$ as being highly credible. The respondents indicated their level of agreement on a social contagion at a moderate level with the average value between 2.671 and 3.649. In addition, they had a moderate level of anxiety (means ranging between 2.214 and 3.829), and a moderate tendency to perform panic buying behavior (means between 2.574 and 3.577). Based on the results of the validity and reliability tests, 9 indicators were excluded from the analysis due to validity (factor loading $<0.5$ ) and multicollinearity (VIF $>5$ ) problems. After removing these indicators, the remaining 34 indicators had factor loading values between 0.6324 and 0.8714 , an AVE between 0.5180 and 0.6496 , a Cronbach's alpha between 0.7826 and 0.9219 , and a composite reliability between 0.8470 and 0.9365 . These items also fulfilled the criteria for discriminant validity (Table 2 ) and HTMT.90 (Table 3).

Table 2

Results of Discriminant Validity Test with Fornell-Larckner Criterion

\begin{tabular}{lllll}
\hline Variables & Consumer Anxiety & Medium Credibility & Message Credibility & Social Contagion \\
\hline Consumer Anxiety & 0.7494 & & & \\
Medium Credibility & 0.2582 & 0.7664 & & \\
Message Credibility & 0.2376 & 0.7733 & 0.8060 & 0.7197 \\
Panic Buying & 0.6314 & 0.2879 & 0.3139 & 0.6205 \\
Social Contagion & 0.6043 & 0.3657 & 0.3833 & 0.7262 \\
\hline
\end{tabular}

\section{Table 3}

Discriminant Test Results with HTMT.90

\begin{tabular}{lcc} 
& Variables & HTMT $<\mathbf{0 . 9 0}$ \\
\hline Medium Credibility - Consumer Anxiety & & 0.3271 \\
Message Credibility - Consumer Anxiety & & 0.2695 \\
Message Credibility - Medium Credibility & & 0.8814 \\
Social Contagion - Consumer Anxiety & 0.6976 \\
Social Contagion - Medium Credibility & 0.4946 \\
Social Contagion - Message Credibility & 0.4739 \\
Social Contagion - Panic Buying & & 0.7064 \\
Panic Buying - Consumer Anxiety & 0.7054 \\
Panic Buying - Medium Credibility & 0.3442 \\
Panic Buying - Message Credibility & 0.3552 \\
\hline
\end{tabular}

\subsection{Multicollinearity between constructs (VIF)}

A multicollinearity test aims to determine whether the correlation between independent variables is high or not. According to Hair et al. (2016), a VIF below 5.0 is acceptable due to the low correlation between independent variables. As presented in Table 4, there was no multicollinearity issue in this study.

\section{Table 4}

Inter-construct Multicollinearity Testing Results

\begin{tabular}{lcc}
\multicolumn{1}{c}{ Independent Variables } & Dependent Variables & VIF $<\mathbf{5 . 0}$ \\
\hline Media Credibility & Consumer Anxiety & 1.1919 \\
Social Contagion & & 1.1919 \\
\hline Media Credibility & Panic Buying & 1.1926 \\
Social Contagion & & 1.7513 \\
Consumer Anxiety & & 1.5760 \\
\hline
\end{tabular}

\subsection{The coefficient of determination (R-Square)}

In this study, the media credibility variable is the second-order factor, where the variable is formed by the medium credibility and message credibility variables. While for testing the consumer anxiety determination coefficient, the R-Square result is 0.3655 ; so, it can be concluded that $36.55 \%$ of media credibility and social contagion variables can explain changes in consumer anxiety variables, while the remaining $63.45 \%$ is explained by other variables. Panic buying behavior is thought to have been influenced by media credibility, social contagion, and consumer anxiety, and it was found that the three variables can explain panic buying behavior by $49.43 \%$. From the R-Square values above, it can be concluded that the coefficient of determination in this study was moderate.

\subsection{Hypothesis testing}

In this study, the media credibility variable is the second-order factor, where the variable is formed by medium credibility and message credibility. While testing the consumer anxiety, it was found that media credibility and social contagion could explain the variability in consumer anxiety by $36.55 \%$. Panic buying behavior was thought to be influenced by media credibility, social contagion, and consumer anxiety, and it was found that these variables could explain panic buying behavior by $49.43 \%$. 
As shown in Table 5, two hypotheses were rejected and three were supported. The hypotheses about the effects of media credibility on consumer anxiety $(\beta=0.0215, p$-value $=0.6801)$ and panic buying behavior $(\beta=0.0822, p$-value $=0.0731)$ were not supported by the data, because they were not statistically significant. This finding contradicts the results of Szabo and Hopkinson (2007), who stated that broadcasted news can trigger negative emotions such as anxiety. This study, however, reported that media credibility does not affect customer anxiety during the COVID-19 pandemic.

\section{Table 5}

Results of Hypotheses Testing

\begin{tabular}{llcccc}
\hline & \multicolumn{1}{c}{ Hypothesis } & $\boldsymbol{\beta}$ & S.E. & T-value & P-values \\
\hline H1 & Media Credibility $\rightarrow$ Consumer Anxiety & 0.0215 & 0.0511 & 0.4123 & 0.6801 \\
H2 & Media Credibility $\rightarrow$ Panic Buying & 0.0822 & 0.0461 & 1.7925 & 0.0731 \\
H3 & Social Contagion $\rightarrow$ Consumer Anxiety & 0.5970 & 0.0430 & 13.8656 & 0.0000 \\
H4 & Social Contagion $\rightarrow$ Panic Buying & 0.3455 & 0.0504 & 6.8434 & Not Supported \\
H5 & Consumer Anxiety $\rightarrow$ Panic Buying & 0.4035 & 0.0492 & 8.1615 & Supported \\
\hline
\end{tabular}

In accordance with Soenarno et al. (2015), the distribution of information via the Internet makes the audience unable to trace the information source easily. While it is expected consumers will be less anxious if they receive information about the COVID-19 pandemic from trusted media, this study found an insignificant effect. It might be because the respondents are generally young people who obtain information about COVID-19 from social media. As such, they are not directly influenced by the media since they are not certain about the credibility of the content of the information since there are hoaxes about this pandemic. They probably just look at the headlines of the news and the big issues regardless of whether the media is credible or not. The respondents stated that they often use media, including social media, to obtain a better understanding of the impact of COVID-19 and know about what is happening. Furthermore, it might be related to the period of data collection in which we collected data not at the beginning of the pandemic. The information in the media during our data collection period presented the situation as being relatively under control, which may contribute to our finding of the less relevant effect of media credibility on consumer emotions. Likewise, the influence of media credibility on panic buying behavior was not supported, which is not in line with the research of Suciningtyas (2012) who found a positive influence of media on consumer purchasing decisions. This finding is also different from other studies that reported a significant direct effect of social media on consumer buying interest (Mardiani \& Imanuel, 2013; Putri, 2016). This may be due to differences in the context being studied. Previous studies have seen the effects of media credibility on buying behavior in general, not on a situation with high uncertainty. The insignificant influence of media credibility variables on panic buying might be due to consumer indifference regarding the information credibility related to the existence of a COVID-19 pandemic. People tend to look more at news content related to COVID-19 without finding out more about the media credibility because the information circulating in the media lately is very fast and difficult to trace. The respondents feel that the media sources they frequently access present convincing, valid, logical, accurate, and objective information about COVID-19, so they tend to receive the information favorably.

This study found that social contagion had a direct effect on panic buying $(\beta=0.3455, \mathrm{p}$-value $=0.000)$ and an indirect effect on panic buying through consumer anxiety $(\beta=0.5970, \mathrm{p}$-value $=0.000)$. This finding supports the research by Lux $(1998)$, Orlean (1992), and Temzelides (1997) about social contagion in different study settings. This is caused by the tendency of someone to follow the behavior of others. In this context, individuals do panic buying after they see other people do this behavior. Meanwhile, the indirect effect is in line with Hatfield et al. (1993) who looked at an emotional contagion due to human tendencies to automatically and continuously harmonize facial expressions, sounds, and postures with others in their immediate environment (Hatfield et al., 1993). As proposed by McDougall (1920) and Sullins (1991), social contagion may include the spread of behaviors and emotions. Some respondents stated that they were prone to panic during the COVID-19 pandemic. This feeling will be stronger if they see people around them express the same feeling and make excessive purchases. This panic buying behavior performed by other people by buying products for basic needs and preventing the transmission of the disease is used as a justification for doing the same thing. They also feel the necessity to follow the buying behavior of others. Others' panic buying behavior will cause an individual to feel anxious if the person does not do the same, so that it encourages one to perform the same behavior. The test of the mediation effect showed that consumer anxiety is a partial mediator since both the direct and indirect effects of social contagion on panic buying behavior were statistically significant. This study indicated that consumer anxiety had a significant positive effect on panic buying behavior $(\beta=0.4035$, $\mathrm{p}$-value $=$ 0.000). This finding supports the previous research by Muchnisa and Sulaiman (2019) who found a positive effect of consumer anxiety on compulsive buying. The respondents feel panicked easily during the COVID-19 pandemic because they cannot anticipate the condition and there is no clarity about how long the COVID-19 pandemic will last. In addition, they are afraid of the pandemic itself and about the availability of basic needs and products to prevent the transmission of COVID-19. As the public worries about the availability of staples and preventive goods during the pandemic, more individuals will feel anxious which will lead to panic buying. Furthermore, individuals do panic buying because they do not know when this pandemic will end. Therefore, they buy staple goods and COVID-19 prevention products to anticipate if something worse will happen in the future. Some respondents are stressed if they cannot buy COVID-19 prevention products such as masks and hand sanitizers. This negative emotion prompts them to buy more products during the COVID-19 pandemic to satisfy their psychological needs. This is due to their need to feel safe, where the possession of adequate quantities of COVID-19 prevention products may reduce their anxiety. 


\section{Research implications}

The panic buying behavior as in the case of the COVID-19 pandemic can be seen from a psychological perspective. It may relate with the social contagion and consumer emotions. This study found a significant influence of social contagion on panic buying behavior which explains that an individual's behavior can influence and be imitated by others. In the case of a pandemic, an individual's tendency to panic buying is influenced by the behavior of others who do the behavior in anticipation of food stocks and products to prevent the COVID-19 transmission. As stated in the theory of consumer behavior, social factors such as a reference group and the general public play a significant role in shaping one's buying behavior. In referring to the theory of reasoned action, one of the factors that shape an individual's behavioral intention is subjective norms. Other people's views about an object or certain behavior will influence the individual's tendency to behave according to the expectations of others. During uncertain situations such as the COVID-19 pandemic, some people perceive that panic buying behavior as an anticipatory measure is acceptable. This gives rise to collective justification and stimulates a social contagion, which in turn encourages more and more people to act the same way.

In addition, this study found that a social contagion had a positive effect on consumer anxiety. This shows that social factors may affect others not only cognitively, but also emotionally. During the COVID-19 pandemic, one's emotions turn out to play a significant role in buying behavior. The effects of consumer anxiety on buying behavior are heightened by high uncertainty situations. It can be seen from the large number of people who buy food and other products to prevent themselves from contracting COVID-19. This phenomenon occurs due to the presence of the fear that something bad may happen during the pandemic such as stores being out of stock of food ingredients and COVID-19 prevention products. This finding supports the argument that an individual's buying behavior is influenced by cognitive and affective factors. In certain circumstances, such as in pandemics that have a high degree of uncertainty, affective components may play a greater role than cognitive factors in influencing consumer buying behavior.

The findings of this study give insights to retailers about consumer buying behavior in uncertain situations. Retailers need to pay attention to the consumers' needs during the COVID-19 pandemic due to the inclination of people to do panic buying. The pandemic may cause some individuals to worry about the scarcity of staple goods and COVID-19 preventive products in the market. It makes them feel anxious, and this negative emotion can be transferred to other people in their surrounding environment. Their anxiety stimulates them to do panic buying, which increases the level of anxiety and fear in other individuals. Some consumers feel stressed if they cannot buy products that can prevent them from COVID-19 transmission, especially if there is a concern of an imbalance in supply and demand. When the demand is higher than the supply, prices for basic goods and COVID-19 preventive products will rise to a new equilibrium point. Therefore, to maintain the availability of goods and price stability in the market, retailers should do a proper stock management to adjust the amount of inventory to meet the market demand. Meanwhile, to cope with a surging demand during the pandemic, retailers should work closely with producers to maintain the stock availability. This should also be done to prevent sellers from hoarding goods to seek excessive profits from the situation. Manufacturers of COVID-19 prevention products such as masks, hand sanitizers, and vitamins need to maintain the product availability in the market during the pandemic. They must increase the production capacity so that the product supply can meet the increasing market demand. By learning from the situations in other countries, manufacturers can take anticipatory actions before similar situations occur in Indonesia. Another party that can benefit from this study is the government as the public policymaker. The government needs to facilitate the producers in maintaining the supply for production. Currently, many producers still use imported components, while they often find challenges in terms of the import procedures, import quotas, and the duty fees for imported raw materials. In urgent conditions where the demand is increasing because of a pandemic, producers need to supply more materials and even increase the production capacity. Therefore, the government should simplify the import procedures and reduce the import duty fees to facilitate manufacturers in producing the necessary products such as masks, hand sanitizers, and vitamins in sufficient quantities.

In addition, there is a need for the law enforcement of sellers who deliberately stockpile staples and COVID-19 prevention products. One of the possible actions is by giving sanctions to permanently close the businesses and impose high fines to create a deterrent effect for the price stability and product availability in the market. Another step is to make purchase restrictions to reduce the potential for consumers to do panic buying or stockpiling of goods for resale. Nevertheless, the most important thing is the government should take appropriate, measurable, and fast actions so that the public feels calm during the pandemic. The government should set public policies and urge people not to do panic buying when facing the COVID-19 pandemic. The government and legislative bodies must unite and work together in determining the appropriate actions to solve the situations. In a pandemic situation, every policy and action taken by the government will affect people's perceptions about the government's ability to overcome the problems caused by the pandemic, both in the health and economic aspects.

\section{Conclusion}

This study found that media credibility did not have a significant effect on consumer anxiety and panic buying behavior because this study mainly involved young individuals who do not seem to pay attention to media credibility. As expected, social contagion has an influence on the emergence of consumer anxiety and panic buying. Some individuals feel more afraid 
and panicky during the COVID-19 pandemic, particularly if they see other people around them feel the same and make excessive purchases. The buying behavior of other people becomes a justification in deciding to do the same by perceiving it as being necessary to follow other people's buying behavior. The panic buying behavior of others will cause some individuals to feel anxious if they do not do the same thing, so that it encourages them to take the same action. Lastly, consumer anxiety during the COVID-19 pandemic also has a significant influence on panic buying behavior. This is due to the public anxiety and fear regarding the availability of staples or foodstuffs as well as how to keep stocks of COVID-19 prevention products. Anxiety and fear stimulate individuals to do panic buying because there is no clarity when this pandemic will end, and the availability of basic and COVID-19 preventive goods is uncertain.

\section{Suggestions for future research}

This study has several limitations. First, the data was collected only in Greater Jakarta, while the virus has spread rapidly in more provinces nowadays that have high COVID-19 transmission rates. Future research may consider including individuals in other provinces or countries as their reactions to the pandemic may differ. Second, the scope of panic buying in this study was only centered on the purchase of staple and COVID-19 prevention goods. Last, this study focused only on consumer emotions, social contagion, and media credibility as determinants of panic buying behavior. Further research may consider expanding the scope associated with the COVID-19 pandemic and look for other variables such as perceived risk, government intervention, and consumer well-being.

\section{References}

Abidin, S., Cindoswari, A. R., \& Gea, S. (2017). Kredibilitas media dalam pemberitaan implementasi kawasan ekonomi khusus kota Batam. Jurnal Komunikasi Hasil Pemikiran dan Penelitian, 3(1), 72-78.

Angst, Corey \& Agarwal, Ritu \& Sambamurthy, Vallabh \& Kelley, Ken. (2010). Social contagion and information technology diffusion: The adoption of electronic medical records in U.S. hospitals. Management Science, 56(8), 1219-1241. https://doi.org/10.1287/mnsc. 1100.1183

Annisa, D. F., \& Ifdil. (2016). Konsep kecemasan (anxiety) pada lanjut usia (lansia). Konselor, 5(2), 93-99. https://doi.org/10.24036/02016526480-0-00

Atkin, C., Greenberg, B., Korzenny, F., \& McDermott, S. (1979). Selective exposure to televised violence, Journal of Broadcasting, 23(1), 5-13. https://doi.org/10.1080/08838157909363912

Bahari, A. F., \& Ashoer, M. (2018). Pengaruh budaya, sosial, pribadi dan psikologis terhadap keputusan pembelian konsumen ekowisata. Jurnal Manajemen, Ide, Inspirasi (MINDS), 5(1), 69-78. https://doi.org/10.24252/minds.v5i1.4839

Behnke, P. R., Sawyer, C. R., \& King, P..E. (1994). Contagion theory and the communication of public speaking state anxiety. Communication Education, 43(3), 246-251.

Burgess, L. G., Riddell, P. M., Fancourt, A., \& Murayama, K. (2018). The influence of social contagion within education: A motivational perspective. International Mind, Brain and Education Society and Wiley Periodicals, Inc. 12(4), 164-174. https://doi.org/10.1111/mbe. 12178

Christakis, N. A., \& Fowler, J. H. (2013). Social contagion theory: Examining dynamic social networks and human behavior. Statistics in Medicine. 32(4), 556-577. doi:10.1002/sim.5408

Darrat, A. A., Darrat, M. A., \& Amyx, D. (2016). How impulse buying influences compulsive buying: The central role of consumer anxiety and escapism. Journal of Retailing and Consumer Services, 31, 103-108. https://doi.org/10.1016/j.jretconser.2016.03.009

Doherty, R. W. (1997). The emotional contagion scale: A measure of individual differences. Journal of Nonverbal Behavior, 21, 131-154. https://doi.org/10.1023/A:1024956003661

Fetzer, T., Hensel, L., Hermle, J., \& Roth, C. (2020, March 21). Coronavirus perceptions and economic anxiety. Vox CEPR Policy Portal. Retrieved from https://voxeu.org/article/coronavirus-perceptions-and-economic-anxiety

Freedman, J. L., \& Perlick, D. (1979). Crowding, contagion, and laughter. Journal of Experimental Social Psychology, 15(3), 295-303. https://doi.org/10.1016/0022-1031(79)90040-4

Freedman, J. L., Birsky, J., \& Cavoukian, A. (1980). Environmental determinants of behavioral contagion: Density and number. Basic and Applied Social Psychology, 1(2), 155-161. https://doi.org/10.1207/s15324834basp0102_4

Garson, G. D. (2016). Partial least squares: Regression \& structural equation models. Asheboro, NC: Statistical Publishing Associates.

Guale, R. A., \& Beltrán, F. V. (2017). Personal interaction and its effect on the purchase decision. Revista de Ciencias de la Administración y Economía, (13)7, 153-167. http://dx.doi.org/10.17163/ret.n13.2017.09

Gump, B. B., \& Kulik, J. A. (1997). Stress, affiliation, and emotional contagion. Journal of Personality and Social Psychology, 72(2), 305-319. https://doi.org/10.1037/0022-3514.72.2.305

Hair Jr, J. F., Hult, G. T. M., Ringle, C. M., \& Sarstedt, M. (2016). A primer on partial least squares structural equation modeling (PLS-SEM). Thousand Oaks, CA: Sage Publication

Handiyani, P., \& Hermawan, A. (2017). Kredibilitas portal berita online dalam pemberitaan peristiwa bom Sarinah tahun 2016 (Analisis isi portal berita detik.com dan kompas.com periode 14 Januari-14 Februari 2016). Jurnal Komunikasi, 12(1), 51-68. https://doi.org/10.20885/komunikasi.vol12.iss1.art4 
Hatfield, E., Cacioppo, J. T., \& Rapson, R. L. (1993). Emotional contagion. Current Directions in Psychological Science, 2(3), 96-100. https://doi.org/10.1111\%2F1467-8721.ep10770953

Helsloot, I., \& Ruitenberg, A.. (2004). Citizen response to disasters: A survey of literature and some practical implications. Journal of Contingencies and Crisis Management, 12(3), 98 - 111. DOI: 10.1111/j.0966-0879.2004.00440.x.

Herwanto \& Febyani, S. (2015). Kecemasan terhadap berita hoax ditinjau dari strategi emosi pada millennial mom. Jurnal Penelitian dan Pengukuran Psikologi, 4(1), 1-15. https://doi.org/10.21009/JPPP.041.03

Hsee, C. K., \& Hatfield, E., \& Carlson, J. G., \& Chemtob, C. (1990). The effect of power on susceptibility to emotional contagion. cognition \& emotion. Cognition and Emotion, 4(4), 327-340. 10.1080/02699939008408081

Huang, L. (2010). Social contagion effects in experiential information exchange on bulletin board systems. Journal of Marketing Management, 26(3-4), 197-212. https://doi.org/10.1080/02672571003594770

Hutjens, M. (2014). The influence of fear on the buying behavior of consumers in case of an animal disease outbreak. Retrieved from https://edepot.wur.nl/318026

Infeksiemerging. (2020, April 17). Situasi terkini perkembangan coronavirus disease (covid-19) 17 April 2020. Retrieved from https://covid19.kemkes.go.id/situasi-infeksi-emerging/info-corona-virus/situasi-terkini-perkembangan-coronavirusdisease-covid-19-17-april-2020/

Jurnaiti, Lubis, A. R., \& Hafasnudin. (2017). Pengaruh consumer involvement, kredibilitas sumber informasi dan kepuasan konsumen terhadap keputusan pembelian ulang (studi pada konsumen obat pada apotek di kota Banda Aceh). Jurnal Perspektif Manajemen dan Perbankan, 8(3), 135-157.

Kawengian, K., Mingkid, E., \& Pantow, J. T. (2017). The role of government communications in implementation of kampung clean program (Study on village government Lopana One District Amurang East). E-journal "Acta Diurna", 5(2). https://media.neliti.com/media/publications/95060-ID-peranan-komunikasi-pemerintah-dalam-pela.pdf

Kosasih, E. J., Setianti, Y., \& Wahyudin, U. (2017). Pengaruh kredibilitas petugas terhadap sikap kepatuhan pasien tuberkulosis pada pemeriksaan dahak. Jurnal Kajian Komunikasi, 5(1), 1-10. https://doi.org/10.24198/jkk.v5i1.8480

Kulemeka, O. (2010). Us consumers and disaster: Observing "panic buying" during the winter storm and hurricane seasons. Association for Consumer Research, 37, 837-838. https://www.acrwebsite.org/volumes/14976/volumes/v37/NA-37

Kumbara, H., Metra, Y., \& Ilham, Z. (2018). Analisis tingkat kecemasan (anxiety) dalam menghadapi pertandingan atlet sepak bola Kabupaten Banyuasin pada Porprov 2017. Jurnal Ilmu Keolahragaan, 17(2), $28-35$. https://doi.org/10.24114/jik.v17i2.12299

Larasati, M. A., \& Budiani, M. S. (2014). Hubungan antara kontrol diri dengan pembelian impulsif pakaian pada mahasiswi psikologi Universitas Negeri Surabaya yang melakukan pembelian secara online. Jurnal Penelitian Psikologi, 2(3), 1-8.

Lejoyeux, M., Tassain, V., Solomon, J., \& Adès, J. (1997). Study of compulsive buying in depressed patients. The Journal of Clinical Psychiatry. 58(4), 169-173. https://doi:10.4088/jcp.v58n0406

Lestari, Y., Latif, S., \& Widiastuti, R. (2013). Mengurangi kecemasan siswa di sekolah dengan menggunakan teknik desensitisasi sistematis. ALIBKIN (Jurnal Bimbingan Konseling), 2(3), 1-12.

Li, R., \& Suh, A. (2015). Factor influencing information credibility on social media platforms: Evidence from Facebook pages. Procedia Computer Science, 72. 314-328. https://doi.org/10.1016/j.procs.2015.12.146

Lux, T. (1998). The socio-dynamics of speculative markets: Interacting agents, chaos, and the fat tails of return distribution. Journal of Economic Behavior and Organization, 33(2), 143-165.

Mardiani, I. E., \& Imanuel, O. J. (2013). Analisis keputusan pembelian konsumen melalui media online (E- marketing). Jurnal Ekonomi, 4(2), 153-154.

Marsden, P. (1998). The Selectionist Paradigm: More Implications for Sociology. Sociological Research Online, 3(4), 1-11. https://doi.org/10.5153\%2Fsro.195

Marsden, P. (1998). Memetics and social contagion: Two sides of the same coin? Journal of Memetics - Evolutionary Models of Information Transmission, 2(2), 171-185.

Merrefield, C. (2020, March 18). Hoarding and panic buying: 4 studies to know. Journalist's Resource Research on Today's News Topics. https://journalistsresource.org/studies/economics/hoarding-panic-buying-coronavirus-research/

Muchnisa, F., \& Sulaiman. (2020). Pengaruh pembelian impulsif terhadap kecemasan konsumen yang berdampak pada pembelian kompulsif dan dimediasi oleh eskapisme (Studi kasus pada matahari departement store di Banda Aceh). Jurnal Ilmiah Mahasiswa Ekonomi Manajemen, 5(1), 236-249.

Orlean, A. (1992). Contagion of opinion in financial markets. Revue Economique, 43(4), 685-698.

Pamungkas, B. A., \& Zuhroh, S. (2016). Pengaruh promosi di media sosial dan word of mouth terhadap keputusan pembelian (Studi kasus pada kedai Bontacos, Jombang). Jurnal Komunikasi, 10(2), $145-160$. https://doi.org/10.21107/ilkom.v10i2.2518

Ple, L., \& Demangeot, C. (2019). Social contagion of online and offline deviant behaviors and its value outcomes: The case of tourism ecosystems. Journal of Business Research, 1-11. https://doi.org/10.1016/j.jbusres.2019.06.002

Putri, C. S. (2016). Pengaruh media sosial terhadap keputusan pembelian konsumen cherie melalui minat beli. PERFORMA: Jurnal Manajemen dan Start-Up Bisnis, 1(5), 594-603.

Qiu, W., Chu, C., Mao, A., \& Wu, J. (2018). The impact on health, society, and economy of SARS and H7N9 outbreaks in China: A case comparison study. Journal of Environmental and Public Health, 1-7. https://doi.org/10.1155/2018/2710185

Shou, B., Xiong, H., \& Shen, Z. M. (2011). Consumer panic buying and fixed quota policy. Working paper. City University of Hong Kong. Kowloon Tong. http://personal.cb.cityu.edu.hk/biyishou/Consumer_panic_buying.pdf 
Soenarno, A. R., Suharyono, \& Mawardi, M. K. (2015). Analisis pengaruh kualitas informasi dan kredibilitas sumber terhadap kegunaan informasi dan dampaknya pada adopsi informasi (Studi pada masyarakat pengikut akun Twitter resmi iKaskus). Jurnal Administrasi Bisnis (JAB), 25(2), 1-7.

Suciningtyas, W. (2012). Pengaruh brand awareness, brand image, dan media communication terhadap keputusan pembelian. Management Analysis Journal, 1(1), 1-8.

Sunarto. (2018). Analisis perilaku konsumen terhadap keputusan pembelian handphone Xiaomi Redmi 3S. Jurnal Moneter, $5(2), 35-43$.

Szabo, A., \& Hopkinson, K. L. (2007). Negative psychological effects of watching the news in the television: Relaxation or another intervention may be needed to buffer them. International Journal of Behavioral Medicine, 14(2), 57-62.

Temzelides, T. (1997). Evolution, coordination, and banking panics. Journal of Monetary Economics, 40(1), $163-183$. https://doi.org/10.1016/S0304-3932(97)00033-0

The Bronfenbrenner Center for Translational Research. (2020, March 24). The science of panic buying and how to stop it. Psychology Today. https://www.psychologytoday.com/us/blog/evidence-based-living/202003/the-science-panic-buyingand-how-stop-it

Tsao, Y. -C., Raj, P. V. R. P., \& Yu, V. (2018). Product substitution in different weights and brands considering customer segmentation and panic buying behavior. Industrial Marketing Management, 77, $209-220$. https://doi.org/10.1016/j.indmarman.2018.09.004

Utami, F. A. (2020, April 13). Apa itu panic buying? Warta Ekonomi. https://www.wartaekonomi.co.id/read280798/apa-itupanic-buying

Van Bavel, J. J., Boggio, P., Capraro, V., Cichocka, A., Cikara, M., Crockett, M., \& Willer, R. (2020). Using social and behavioral science to support covid-19 pandemic response. Nature Human Behavior , 4, 460-471. https://doi.org/10.1038/S41562-020-0884-Z

Viviani, M., \& Pasi, G. (2017). Credibility in social media: Opinions, news, and health information-A survey. Wiley Interdisciplinary Reviews: Data Mining and Knowledge Discovery, 7(5), e1209. https://doi.org/10.1002/widm.1209

Widigda, I. R., \& Setyaningrum, W. (2018). Kecemasan mahasiswa pendidikan matematika Universitas Riau Kepulauan dalam menghadapi skripsi. Jurnal Pendidikan Matematika dan Sains, 6(2), 190-199. https://journal.uny.ac.id/index.php/jpms/article/view/23963/pdf

Wijayanti, P. A., \& Sulistiobudi, R. A. (2018). Peer relation sebagai prediktor utama school well-being siswa sekolah dasar. Jurnal Psikologi, 17(1), 56-67. https://doi.org/10.14710/jp.17.1.56-67

Worldometer. (2020). Covid-19 coronavirus pandemic. Retrieved from https://www.worldometers.info/coronavirus/

Yap, A. J., \& Chen, C. Y. (2020). The psychology behind coronavirus panic buying. Knowledge. Retrieved from https://knowledge.insead.edu/economics-finance/the-psychology-behind-coronavirus-panic-buying-13451

Yu, L., Li, L., \& Tang, L. (2016). What can mass media do to control public panic in accidents of hazardous chemical leakage into rivers? A multi-agent-based online opinion dissemination model. Journal of Cleaner Production, 143, 1203-1214. https://doi.org/10.1016/j.jclepro.2016.11.184

Zheng, R., Shou, B., \& Yang, J. (2020). Supply disruption management under consumer panic buying and social learning effects. Omega (in press). https://doi.org/10.1016/j.omega.2020.102238

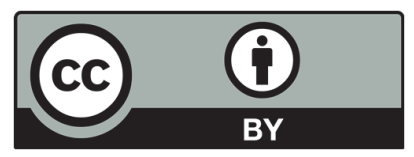

(C) 2021 by the authors; licensee Growing Science, Canada. This is an open access article distributed under the terms and conditions of the Creative Commons Attribution (CC-BY) license (http://creativecommons.org/licenses/by/4.0/). 